\title{
Palimpsests of the past: invoking heritage in the redevelopment of post-war housing estates
}

\author{
Y. H. Tan \\ University of Leicester, $U K$
}

\begin{abstract}
The transformation of the urban landscape is as much a physical process as it is symbolic. Demolitions and new developments bring about changes in the identity of places, as well as irreplaceable loss in personal and collective memories associated with these old places. The use of heritage in redevelopment schemes, through the conservation of buildings or revoking the culture and memory of old places, is seen as an increasingly common way to soften the impact of redeveloping the built environment. Focusing on two redevelopment schemes in Glasgow and Singapore, this paper explores the value of heritage as an integral part of redevelopment despite their seemingly opposing natures. The Crown Street Redevelopment Scheme in Gorbals, Glasgow and the one-north Masterplan in Queenstown, Singapore are presented here as case studies to show how economic, political and cultural forces have interacted to produce built environments which juxtaposes the new with the old. Elements from the postwar housing past are eliminated and ignored while new forms of "heritage" are conceived, celebrated and integrated with new development plans.

Keywords: heritage, post-war housing, urban redevelopment, collective memory, adaptive reuse.
\end{abstract}

\section{Introduction}

Cities are changed physically as their economies undergo transformation. The functions of cities are continually reconceptualised and modified by different agencies to fulfil various urban objectives. Post-war housing estates are especially susceptible to continuous evaluation of the role these places play in meeting the demands of a wealthier populace demanding a higher quality of life. As post-war public housing was initially conceived to meet basic housing needs 
of the populace, it could no longer meet the rising expectations and aspirations of an affluent population. In response, a multitude of private housing ranging from luxury apartments to standalone houses was developed. There is thus growing pressure for public housing development to upgrade existing post-war housing facilities and provide more varied housing options in new developments in order to retain support from the populace.

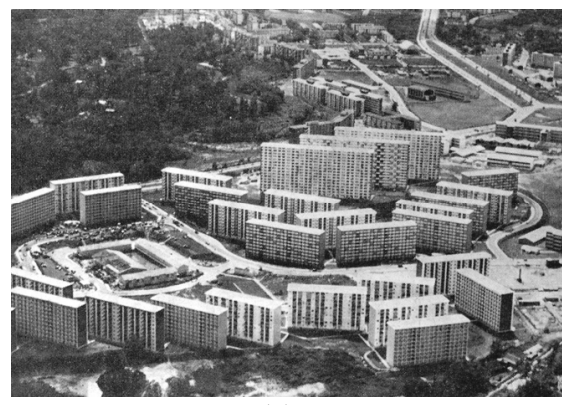

(a)

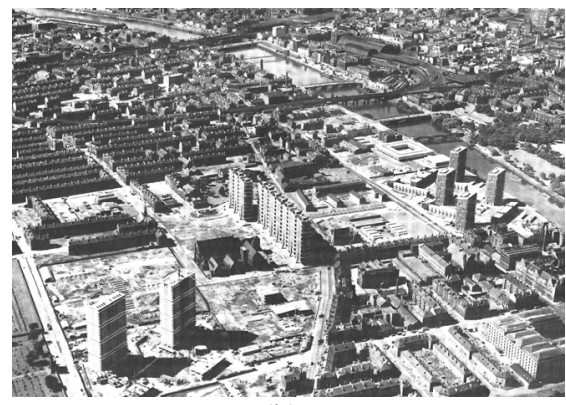

(b)

Figure 1: (a) Queenstown, Singapore, 1961 (source: Low [18, p. 69]); (b) Hutchesontown-Gorbals CDA, 1965 (source: Horsey [30]).

This paper will explore the utilisation of heritage to attain societal and economic aims, in relation to the Crown Street and the one-north redevelopment schemes. The paper will show how the representation of heritage in these two cases is selective and strategic to sculpting a new image of the estate that will appeal to a sophisticated market. On one hand, housing planners actively historicised the post-war housing estate; while on the other hand, they were obliterating the extant landscape and its existing social structure to create an environment whereby the old complied with the needs of the new. The idealised schemes reconstructed the past by fulfilling the demands of the buyers, thereby ensuring profitability and economic viability. The selective elimination of undesirable aspects from the post-war housing era, coupled with reconstructing or revoking favourable events from the distant past, thus served the purpose of keeping history "tidy and suitable" for contemporary uses [1].

\section{Post-war housing changes in Glasgow and Singapore}

Post-war housing research have predominately focused on the discussion of issues within a single housing estate, in a single country or confined to the western or Asian context. Home's Of Planting and Planning: The making of British colonial cities explored how British town planning concepts had been exported worldwide. These concepts are modified and crafted in ways that suited local conditions. With time, each former colony, such as Singapore, acquired urban planning strategies that are reminiscent of its colonial administration but updated to handle modern day challenges [2]. 
Sharing the same roots in early 1900s British town planning concepts, postwar housing in Singapore was conceived to meet the immense challenges of post-war reconstruction and the rapid growth of the population. Various researchers have discussed the lack of attention given to low-cost housing in Singapore before the war. The Singapore Improvement Trust (SIT), though established in 1927, was not "empowered as a statutory board to carry out housing projects" for the masses [3]. This led on to widespread resentment against the colonial housing authority, so much so after World War II, official attempts to clear urban kampongs (villages) to build new public housing were "deeply contested and frequently resulted in social and political conflict" [4]. This situation persisted until 1960 when the Housing Development Board (HDB) was established as the self-governing colony's housing authority. Since then, HDB became synonymous with public housing in Singapore, with more than $87 \%$ of the population living and owning subsided HDB flats. In tandem with the rapid industrialisation and economic growth in Singapore from 1965, public housing has been discussed as a major "contribution towards higher wages and productivity, political and social stability" thereby attracting "international capital and manufacturing investments" into Singapore [5]. However increasingly, the middle class is "rejecting public housing as a mass produced consumer good", thus necessitating the upgrade of existing post-war housing estates to attract the middle class.

Like Singapore, Glasgow was known as a busy industrial port city which facilitated trade within and beyond the British Empire. By the $18^{\text {th }}$ century, Glasgow had become a "boom town", enriched by shipping and new world trade, particularly in tobacco and cotton. By the $20^{\text {th }}$ century, the city was renowned for its innovative heavy industrial activities, such as ship and locomotive building [6]. Rapid industrialisation of the city influenced the city's urban structure. Residential tenements and industrial buildings often stood side by side. As the central area of the city became more crowded, industrial buildings and workers' housing started encroaching into the inner city where abandoned middle-class tenement houses were taken over by workers. By the end of World War Two, Glasgow continued to face problems such as overcrowding, poor housing facilities and a dire need to house families displaced by the war.

Architecture in the form of post-war public housing was seen as the herald of better living standards and a closure to the ravages of the war-time years. Slum clearances and the construction of modern housing blocks were initiated in Glasgow to eradicate the vestiges of tenements associated with the grim Victorian industrial period. In 1954, the Glasgow Development Plan designated the Gorbals, Govan and Royston inner city tenement areas for immediate demolition and comprehensive redevelopment. The Hutchesontown Comprehensive Development Area (CDA) Plan was subsequently submitted in 1956 and approved the following year. The redevelopment plan was phased over 20 years from 1957 to 1977 where five land parcels, Area A to E, were developed. According to Thompson-Fawcett, the development of housing projects in the inner city grew rapidly as the area was expected to "act as a stimulant for further economic growth and attracting funds" for Glasgow [7, 
pp. 181-182]. By the 1970s, housing developments in the Gorbals came to be viewed as a critical factor in stimulating wider economic recovery in "housingled regeneration". The Scottish post-war housing project was a success. At the height of post-war housing programme worldwide in the $1960 \mathrm{~s}, 79 \%$ of all new housing developments in Scotland were built by the public authorities. Of which, $96 \%$ of Glasgow post-war housing was built by public authorities [8].

\section{From Hutchesontown Area E to Crown Street}

Part of the present Crown Street Redevelopment Project is situated in the former Hutchesontown Area E. Construction was carried out between 1968 and 1974. It consisted of 12 seven storeys linked deck access blocks with 759 flats and two 24 storey point blocks with 384 flats [9]. Soon after completion, the deck access blocks were plagued by a plethora of building defects related to dampness, such as black mould and rotting carpentry [7, p. 184]. The development was soon given the unsavoury nickname "The Dampies". After an intense tenants' campaign, the local council agreed to relocate remaining residents and the blocks were abandoned in 1980. The deck-access blocks were subsequently demolished in 1987 , leaving a 40 acre site which remained vacant for close to a decade [10, p. 5].

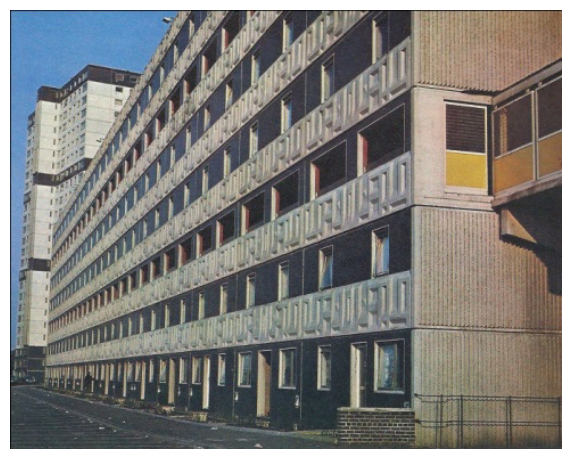

(a)

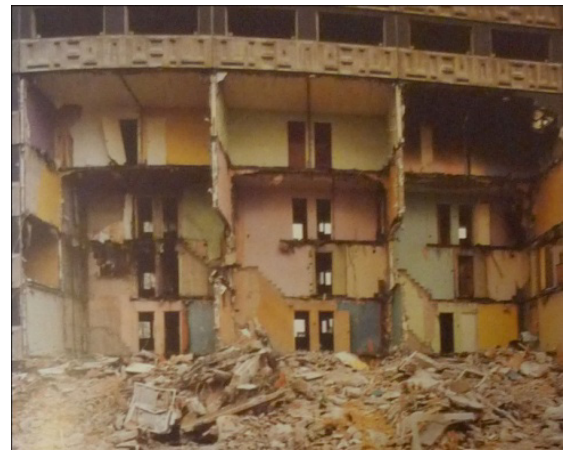

(b)

Figure 2: (a) Area E in 1974 (source: Reoch [31]) and (b) its demolition in 1987 (source: Crown Street Regeneration Project [32]).

The demolition of Hutchesontown $\mathrm{E}$ was the harbinger for more demolitions within the Hutchesontown Comprehensive Redevelopment Area. By early 1990s, Gorbal's post-war housing landscape had "lost its identity and the vacant deck-access blocks lining principal thoroughfares depressed the environment." [11]. The Crown Street Regeneration Project was thus conceived in 1990 with the intention to reverse unpopular CDA housing schemes and to develop residential housing which will fill the "gaping hole in the urban fabric" after the demolition of the 12 deck-access blocks in Area E [10, p. 6]. It was chosen for both its visual and historical prominence in Glasgow. Apart from being close to 
the city centre, Crown Street is also the "southern prolongation of High Street and Saltmarket, the medieval north-south axis of Glasgow" [7, p. 185]. Undoubtedly, the prominence of the site meant that the Crown Street Redevelopment Project was destined to become a showpiece for Glasgow, which its planner hoped would serve as "a catalyst...which would attract further investments, further confidence in the Gorbals as an area" [12].

\section{Crown Street: the liveable city}

Three years after the demolition, a major urban design competition was held in 1990 to redevelop the vacant 40-acre site as Crown Street Redevelopment Project. It comprised of the former Area E, as well as the undeveloped land in the west of Hutchesontown/Gorbals. Of the 4 architectural firms invited to participate, CZWG Architects from London was chosen. A main feature of their urban design scheme called for the "abolishment of the open Modernist spatial conception and to recreate streets lined with façade of four-storey mixed tenure housing enclosing communal gardens" [13]. The objective was to create a "liveable city" which the planners claimed the CDA housing had failed to provide. Life in the tower block was dismissed as a "hard-edged city life" which caused "duress" and a lack of "dignity and calm". The firm proposed adopting the traditional tenement block and the Glasgow street pattern from the late $19^{\text {th }}$ century as a solution for improving the quality of life in Crown Street. By denouncing the failures of the previous built environment and conjuring a favourable image of historical built forms from an earlier phase of urban development, an image of Crown Street as the idealised traditional Glasgow neighbourhood was formed. The height of new perimeter blocks is controlled at 4 storeys to convey an impression of harmony and unity "like a late nineteenth century neighbourhood" [10, p. 7]; while white and red sandstone cladding is used on new housing blocks to mimic working-class $19^{\text {th }}$ century tenement blocks, which were hailed as "Glasgow's archetypal building form" [11, p. 2].

The representation of heritage in Crown Street, however, is subjective. The planners for Crown Street had appropriated heritage in order to make the appealing to present buyers. Heritage was seen as part of a process of "careful urban renewal" whereby the historic environment is recreated and reinterpreted to be "more suitable for family and modern life" [11, p. 1]. For example, in a traditional road hierarchy, thoroughfares were the widest roads as they had to carry large number of motorists through a neighbourhood efficiently. Shops would line the both sides of the boulevards as the location is favourable for quick delivery of goods. However in Crown Street Redevelopment Project, planners cited "present day conditions" to suggest that this hierarchy should be reversed. A tree-lined boulevard was reintroduced on Crown Street, the thoroughfare of the neighbourhood. It was, however, not meant for heavy traffic flow. Most traffic in the neighbourhood is diverted to non-pedestrian roads on the fringe. This leaves the Crown Street Boulevard largely empty. Al Fresco dining and outdoor retail spaces were introduced on the walkways to create a "return to the traditional shopping street" [7, pp. 190-192]. Instead of "the filth and 
overcrowding of the city's poor quarter" which Crown Street was known for in the $19^{\text {th }}$ century, the main thoroughfare of Crown Street is created in reminiscence of shopping streets in Europe.

\section{A new urban village in Glasgow}

From its inception, Crown Street Redevelopment Project was conceived as a housing programme that is different from the Comprehensive Development Area tower block housing which had dominated the Gorbals' skyline for three decades. Crown Street Regeneration Project was presented with two distinct execution plans where the planners deemed appropriate and appealing to buyers. Glasgow Development Agency (GDA), a central government body primarily concerned with economic development wanted to restore Glasgow's tenement housing form; while the Glasgow Planning Department preferred the singlefamily houses approach [15]. GDA eventually prevailed despite the reluctance of private developers to be involved in constructing and marketing the new housing. Developers were sceptical about reintroducing an old building typology as part of revitalisation and they were aware of "the stigma attached to the location" [7, p. 186]. The project therefore was largely dependent on public funding and the public sector to execute the project.

The tenement housing in Crown Street only resembled original Gorbals tenements in terms of building scale and façade treatment. The internal layout and functions of the Crown Street housing block had deviated from the original tenement significantly. Original Gorbals tenements were first occupied by middle class and then the working class as Glasgow's industries expanded. The ground floor was used as shopfronts while upper floors were used for housing. The internal layout of the tenement was flexible, changing over time to accommodate different functions such as workshops and the inclusion of more tenants. Residential and commercial functions in tenement areas were not segregated. Invariably, they co-existed within the same building.

In contrast to the mixed residential and commercial nature of the old Gorbals tenements, the new tenement blocks in Crown Street were meant for housing only. Instead of shops on the ground floor, there were units of "maisonette apartments with interior stairwells, three or four bedrooms and a small rear gardens" on the lower floors [10, p. 12]. The design of the new housing blocks catered to a wealthy clientele but lacked the flexibility of functions that $19^{\text {th }}$ century tenements could achieve. As the new housing scheme "desired to create a community rather than another housing scheme" [11, p. 4], auxiliary facilities were created instead of having the neighbourhood develop different functions organically over time. A complementary "Urban Village" concept was mooted to provide a range of facilities with the aim to help the neighbourhood succeed.

The "Urban Village" concept was led by the Urban Villages Forum which included major land developers, local authorities and housing associations. It called for a change to the segregation of housing, employment and retail in town planning by proposing mixed-use developments that "create a balanced and more sustainable urban regeneration" [17]. The aims of the Urban Villages Forum and 
the Crown Street Regeneration Project were analogous. Both denounced the modernist planning approach as a source of "unfriendly residential environments characterised by vandalism, high crime rate and poor security"; likewise both argued for the advantages of "traditional" $19^{\text {th }}$ century mixed-use neighbourhoods which were "dynamic, creative and able to regenerate themselves".

In Crown Street Project, this developed into new facilities such as business centre, budget hotels, student accommodations and small offices. However, the transliteration of the past to the present does not preserve the tenements' essence. $19^{\text {th }}$ century tenements had the flexibility to change internal space configurations to suit commercial and retail needs, but the new units were not able to do so. The planners' need to create a self-sustaining, mixed-use environment within Crown Street neighbourhood resulted in the introduction of new building forms and urban layouts. Crown Street Redevelopment Project could thus be seen as a reimagined $19^{\text {th }}$ century tenement neighbourhood driven by economic aims. Recollection of the old Gorbals neighbourhood is invoked through heritage, yet the past is also reimagined and appropriated to suit new urban and housing conditions in the Crown Street Project.

\section{Queenstown: the first satellite town in Singapore}

Queenstown is the first satellite town established outside Singapore's city area. Planning policies first implemented in Queenstown by the Singapore Improvement Trust (SIT) were subsequently modified and used in the Housing Development Board (HDB) New Towns. The working party for Queenstown was convened in 1953 with the aim of creating a self-sufficient town, complete with health, educational, commercial, religious, recreational and infrastructural facilities [18, p. 164]. It was however more pertinent in the post-war decade to relocate local residents displaced by "redevelopment clearance schemes" in the city and its fringe areas [19, p. 11]. These clearance schemes affected the numerous clusters of unauthorised makeshift dwellings in the city area, also known as urban kampongs. As many squatters worked in the city, kampongs were located close to their workplaces. However, the prevalence of these unauthorised kampongs caused problems such as overcrowding, poor sanitation and difficulty in maintaining law and order. An order was issued by the Municipal Housing Committee in 1947 to resolve the problem through "demolition and re-housing". Queenstown was selected to develop a "selfcontained and balanced" satellite town which would provide housing as well as ample employment opportunities for these squatters [19, p. 11].

Britain's New Town Act was enacted in 1946 for the provision of New Towns in the country. The act was subsequently implemented in British colonies such as Singapore. Unlike the recommended practice of deciding the population of a new town before acquiring land for construction, the Queenstown working party had to work with a pre-allocated 1150 acre site, acquired by the Municipal Government in a piecemeal fashion from 1926 to 1946. Land was initially acquired for railway and military purposes before it was handed to SIT after 


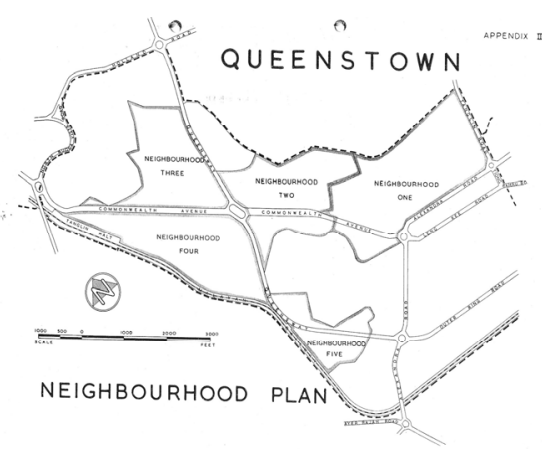

(a)

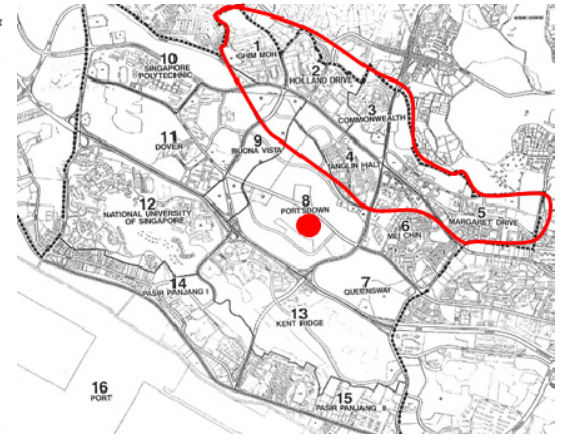

(b)

Figure 3: (a) SIT's Queenstown Neighbourhood Plan (1954) (source: [19, Appendix II]) and (b) HDB Queenstown Planning Report in 1994. The red highlighted area shows the original size of Queenstown Planning Area in relation to the 1990s expansion. Portsdown (Red Dot) is designated the new nucleus of Queenstown (source: URA $[20$, p. 7]).

World War II. An area to the east of the railway was retained by the British Army for use as barracks and officers' quarters. This area, the Pasir Panjang Military Complex, remained in use until the army's withdrawal from Singapore in 1971.

Based on the size of the site, the Working Party had to consider factors such as occupancy densities and the provisions of amenities, industrial areas and open spaces. A figure of 6 persons per average dwelling unit was recommended after studying the population census. This worked out to an average net residential density of 200 persons per acre (ppa). This density allowed for high densities of up to 400 ppa in tall blocks of flats and lower densities of about 150ppa in the low rise blocks and terrace houses [19, pp. 12-13]. Two reasons were cited for such an arrangement. Firstly, only low blocks and terrace houses could be built on reclaimed swamplands while tall blocks built on firm grounds helped achieve the required density. Secondly, Queenstown was intended as the first "balanced society new town" that will attract people from all walks of life. A variety of dwelling types were thus built to attract professionals and middle class to move into the satellite town.

By the time SIT disbanded in 1960, only Princess Margaret Estate had been completed. SIT had envisioned five neighbourhoods in Queenstown which would be able to accommodate a population of 50,000. SIT's succeeding organisation, the Housing and Development Board (HDB) continued post-war housing programmes and took over the planning and construction of Queenstown. As Queenstown proved to be popular with flat applicants, HDB decided to develop two more neighbourhoods. All seven neighbourhoods were completed by mid-1970s with a total population of more than 150,000 . 
Queenstown not only played an important role in alleviating the post-war housing problem, it became the showcase of HDB's public housing efforts in the 1960-70s.

\section{One-North: the "new" new town?}

By 1990, most Queenstown flats were more than 30 years old. The sparsely designed blocks no longer appealed to young Singaporeans. Young Queenstown residents started shifting to other New Towns in the 1980s. The fall in population was accompanied with the decline of industries in Queenstown. In its heyday from 1960s to 1980s, Tanglin Halt Industrial Estate in Queenstown hosted industrial heavyweights such as the Archipelago Brewery Company, Thye Hong Biscuit Factory and Van Houten Chocolates. The 1985 economic recession, however, dealt a heavy blow to Singapore's manufacturing industry. By 1990s, most of Queenstown's factories had closed down or moved to other countries in order to keep manufacturing cost low.

A Planning Report for Queenstown was thus produced by the Urban Redevelopment Authority (URA) in 1994 to revitalise the Satellite Town. The report identified Queenstown's proximity to the universities, Keppel Harbour and the Central Business District as advantages to start a "research-based, hightechnology industrial zone" [20, p. 12]. Portsdown Road, an area separated from Queenstown by thick vegetation and the Malayan Railway Line, was earmarked for development as a high-technology park and residential area. On 4 Dec 2001, the name for the new business park, one-north, was unveiled during the Masterplan exhibition [21].

Zaha Hadid was appointed as Masterplan Consultant to the project in 2000. Her firm was chosen based on its world-class reputation and its track record for "thinking out of the box". The Masterplan envisioned a "work-live-play environment" through locating research laboratories and high technology industries with a variety of housing options and a vibrant "cultural scene" within close proximity. It received much international acclaim and was valorised as the "next generation model for the integration of business, research and urban living" [22]. Yet the concept of integrating commercial and residential buildings within the same development was not new. In many ways, planning concepts found in Queenstown and subsequent New Towns were implemented in OneNorth development despite its "next-generation" moniker. Similar features include having a variety of housing options to attract people from different income groups and the provision of amenities close to residences. Visually, the masterplan had used the hilly terrain to create an innovative "spatial repertoire of natural landscape formations" [23]; ideologically however, the one-north development had not deviated from the New Town planning model. It remains very much reliant on the tested and proved town planning strategies implemented by HDB. In this sense, though the public housing heritage of Singapore is not celebrated, its planning strategy is constantly invoked in new developments. It continues to provide HDB flat dwellers with a sense of familiarity and the expectation of having amenities in close proximity. 


\section{Reimaging neglected sites as reclaimed heritage}

Since Singapore's independence in 1965, the former colonial entreport had developed rapidly into an industrialised city-state. Development of the modern built landscapes came at the price of demolishing built heritage. Large swaths of land were acquired to develop housing estates, office towers and shopping complexes. Rapid and wholesale landscape changes within a generation had caused Singaporeans to feel a loss of identity. The older generation lament the disappearance of an intangible "kampong spirit" or community camaraderie which bonded people of different races together [24].

Conservation of existing buildings is frequently used in redevelopment projects since the 1990s to mitigate the effects of dislocation. Akin to how the one-north development had continued to rely on long-standing housing planning strategies, conservation of existing landmarks was aimed at retaining existing residents' sense of familiarity while preparing them for changes to their physical environment. In the revitalisation project for Queenstown, Prime Minister Lee highlighted the integration of old landmarks in new environments as essential to "retaining the memories and the character of the place". This sense of familiarity is the "something extra which will bring people back" [25]. Yet conservation efforts tend to be selective, agenda-driven and pastiche as PM Lee also mentioned how "the wet market doesn't need look like a wet market anymore", hence only the shell of building is left to evoke memories even though its functions and users had changed according to new needs [26].

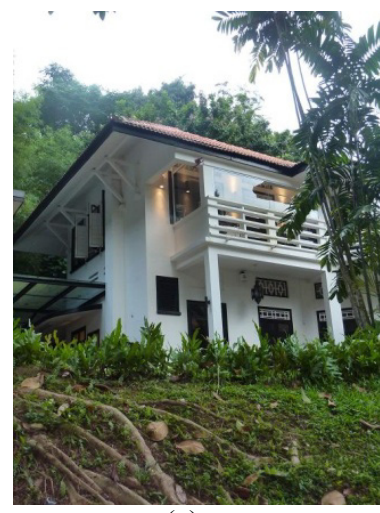

(a)

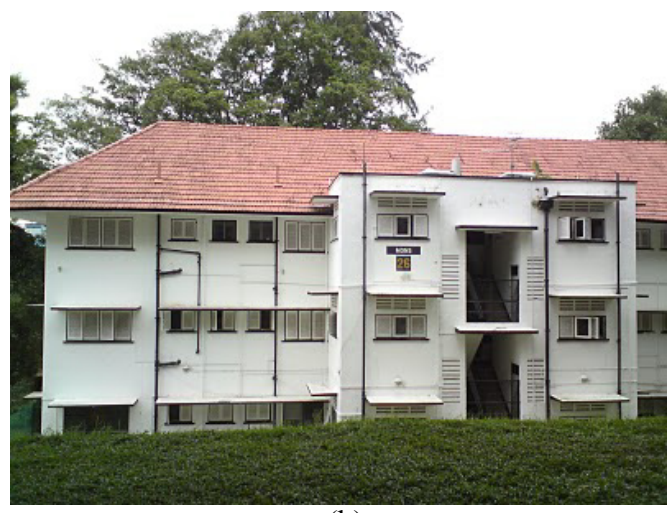

(b)

Figure 4: (a) Colonial "black and white" bungalows and (b) low-rise apartments used as military accommodations in Portsdown Road (sources: (a) The Trek to a Rustic Old Town, http://myqueenstown.blogspot.com, retrieved on 5 Mar 2012 and (b) Rochester Park, http://cbsingapore.blogspot.com/, retrieved on 5 Mar 2012). 
Portsdown Road area in the one-north development is an example of how "little bohemia" are imagined and valorised for national development. As office blocks designed by architects such as Zaha Hadid were constructed in one-north, the former Black and White bungalows and low rise apartment blocks left behind by the British Army were taken over as residences for expatriates and Singaporeans working in one-north. The area was marketed as a "Little Bohemia" in which the entrepreneurial culture could be fostered amidst an idyllic setting [27, pp. 77-80].

The concept of "Little Bohemia" was first promoted by then Senior Minister Lee Kuan Yew in a speech about how an entrepreneurial culture could be developed in Singapore. Lee mentioned "little bohemia" as spaces in which "alternative values, ideas and lifestyles may be tolerated, without contaminating the Asian values of the majority living in public housing estates". Such a notion was elaborated by several other ministers such as then Prime Minister Goh and Deputy Prime Minister Tan. The former military housing at Portsdown Road was identified as a favourable site for such a purpose. It is located within Queenstown as part of the new one-north development, yet remains physically segregated from existing housing estates by railway tracks and thick vegetation.

These black and white houses were largely neglected after the British Army's departure in 1971. Units were rented out cheaply to non-Singaporeans who could neither purchase HDB flats nor afford to rent flats and private accommodations. After Portsdown Road was promoted as a "Little Bohemia", the rental of conserved and refurbished units was restricted only to people in the creative industries or those working in one-north. It fulfilled Jurong Town Corporation's (JTC) objective to create an "environment where talents, entrepreneurs, scientists and researchers would congregate, exchange ideas and interact" [28]. In effect, this elitist community is isolated physically and ideologically from the rest of the "conservative" Singapore society. An image of an "intellectually stimulating and creative environment" is invented to promote Portsdown Road's alternative lifestyle enclave.

Perception of Portsdown Road had changed over the last three decades from a utilitarian military housing estate to a neglected backwater neighbourhood and now a highly sought-after "Little Bohemia". This shows how a historic environment can be reimagined, revived and regulated based on changes to regional and national agendas. About $60 \%$ of Portsdown Road's black and white houses and walk-up apartments were conserved by JTC, while the remainder were demolished. The conservation of these houses was justified as they served as physical embodiments linking past economic struggles and the current national agenda for global success [27, p. 79]. Much as the developer and planners extolled how Singaporeans must not "disregard our heritage or risk losing elements that have brought success", their reasoning is unsound. The military houses were neither a part of Singapore's economic success nor were they previously recognised as part of the nation's built heritage. Unlike vernacular shophouses which were occupied by people of all races, these military accommodations were initially seen as negative vestiges of colonial power in the 


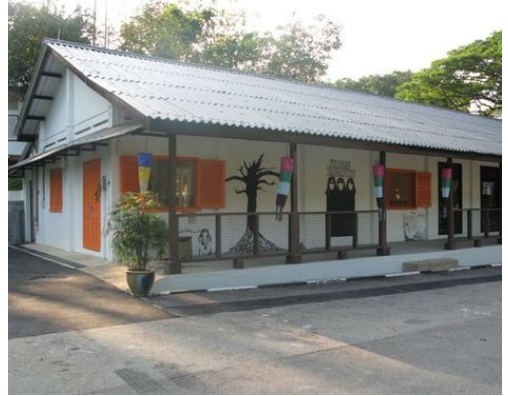

(a)

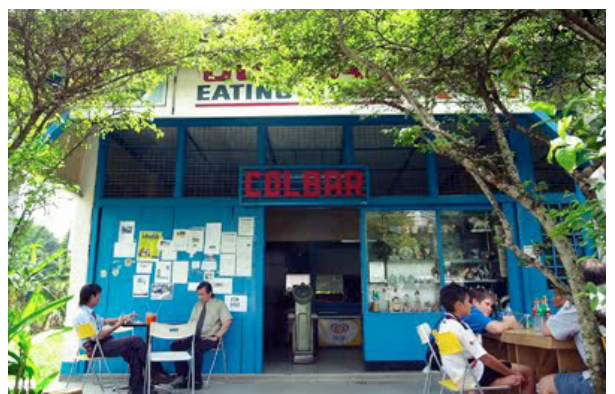

(b)

Figure 5: (a) Single storey buildings are created in the new Wessex Village Square. These buildings are designed to look similar to existing ones such as the relocated ColBar (b). (Sources: (a) Fringe Benefit Gallery, http://fringebenefitsgallery.com/, retrieved on 5 Mar 201 and (b) Colbar, http://epicurative.blogspot.com/2006/04/reviewcolbar-after-seeing-it-reviewed.html, retrieved on 5 Mar 2012.)

early years of nationhood. The rediscovery of the historical Portsdown Road is thus a romanticised narrative aimed to increase one-north's market appeal.

Like perceptions, the built landscape is susceptible to changes. The former military housing units on Portsdown Road were designed to serve as accommodations for soldiers rather than families. During the 1950-70s, the bases in the former Pasir Panjang Military Complex were the most important landmarks in the area. Military bases form important hubs of activities while the black and white military accommodations merely occupied the periphery. As Portsdown Road was re-imagined as a bohemian residential area, this perspective had been reversed. Ageing disused military bases were demolished, leaving behind the black and white houses and apartment blocks. A portion of these apartment blocks were pulled down to create a new town centre for the "Little Bohemia". Art galleries and were built in this new "Wessex Estate Centre". They were designed as single-storey standalone buildings to blend in with the surrounding low-rise houses. Likewise building forms and the material of these structures, such as the gabled roof with clay roof tiles and timber al-fresco dining decks, were chosen to evoke an image of an idyllic colonial town. The cornerstone of the town centre is Colbar, or Colonial Bar, a neighbourhood eatery that has been operating near the military bases since 1953 . The restaurant was forced to move in 2002 as the bases closed down and the land was acquired to build a new road. Instead of demolishing the restaurant, it was carefully dismantled from its original location near the entrance of the military base and reassembled at its new location at the centre of Wessex Estate. The architecture of the eatery is unremarkable, yet every element of the simple timber frame building, from its orange clay roof tiles to its original 1950s countertop and display cabinets, was preserved and relocated. It was as though the restaurant had always existed in that location. The restaurant was preserved not only because it will serve as the new "gathering place for the Wessex community and bohemian 
people" [40]. It also lends legitimacy to the "new" heritage qualities of Portsdown Road and helped enforce the image of a Bohemian enclave, where a faux colonial lifestyle is created and celebrated.

\section{Conclusion}

It is inevitable that post-war housing developments need to be re-imagined and redeveloped. Firstly, the image of cheap and monotonous housing for a needy post-war population no longer resonated with the affluent middle class and a global-trotting community. Secondly, post war housing estates were built upon the total annihilation of the pre-war built environments. People often felt a sense of dislocation in these public housing developments. Many yearn for a return to the idealised past.

Invoking heritage through recreating and appropriating the historical environment is seen as a way to provide continuity between the past and the future. Catch phrases such as "Urban Village" and "Little Bohemia" instantly conjured images of historic environments with modern amenities. Heritage is marketed in the Crown Street Project and the one-north Masterplan development to increase their appeal. Control and manipulation of the historic environment was also aimed at creating an unambiguous and idealised historical narrative which would appeal to house buyers.

The historical environment is seemingly static yet the two cases had shown that historic environments could be moulded to fit different economic and social agendas. However, as different agencies freely interpret and re-imagine these landscapes, they become active agents who shaped the transformation of cities. As history is selectively represented in such environments, conserved or recreated historic buildings often become palimpsests of their past.

\section{References}

[1] Lowenthal (1975) Past time, present place: Landscape and Memory, The Geographic Review LXV (1) pp. 27-28

[2] Home (1997) Of Planting and Planning: The Making of British Colonial Cities, E\& FN Spon, London, pp. 1-7

[3] Tan \& Pang (1991) The Singapore Experience in Public Housing. Times Academic Press, Singapore

[4] Loh (2009) Conflict and Change at the Margins: Emergency Kampong Clearance and the Making of Modern Singapore, Asian Studies Review, Vol. 33 (June) p. 139

[5] Wong and Yap (2002) From universal public housing to meeting the increasing aspiration for private housing in Singapore, Habitat International 27 , p. 363

[6] Moss and Hume (1977) Workshop of the British Empire: Engineering and Shipbuilding the West of Scotland, Heinemann, London 
[7] Thompson-Fawcett (2004) Reinventing the Tenement: Transformation of Crown Street in the Gorbals, Glasgow, Journal of Urban Design, Vol 9 No 2, pp. 181-182

[8] Glendinning (2011) Postwar Mass Housing in Glasgow and Scotland: An Overview, EAHN-DOCOMOMO Tour

[9] Glendinning and Muthesius (1994) Tower Block, Yale University Press, New Haven, p. 368

[10] Urban (2011) Built historiography in Glasgow's New Gorbals-the Crown Street Regeneration Project, Journal of Art Historiography Number 5, p. 5

[11] Galloway (1995) Crown Street Regeneration Glasgow, p. 1

[12] Glendinning (1998) Lecture: Multi-phase modernity: Glasgow's Gorbals, p. 8

[13] Galloway (1995) Crown Street Regeneration Glasgow, p. 1

[14] Thompson-Fawcett (2004) Reinventing the Tenement: Transformation of Crown Street in the Gorbals, Glasgow, Journal of Urban Design, Vol 9 No 2, pp. 190-192

[15] Varady (1996) Neighborhood Regeneration of Glasgow Southside: Implication for American Cities, Journal of Urban Design, Vol 1 Issue 2, p. 203

[16] Galloway (1995) Crown Street Regeneration Glasgow, p. 4

[17] McArthur (2000) Rebuilding sustainable communities, Town Planning Review, Vol 71 (1) p. 51

[18] Low (2007) 10 Stories Queenstown Through the Years, National Heritage Board, Singapore

[19] SIT (1958) Final Report of the New Towns Working Party on the Plan for Queenstown, Tien Wah Press Ltd, Singapore, p. 11

[20] URA (1994) Queenstown Planning Area Planning Report 1994

[21] Tan (2001) Speech at launch of Science Hub, by Deputy Prime Minister, 4 Dec

[22] Architecture and Urbanism (2002) "Zaha Hadid's Masterplan for onenorth in Singapore completed" Vol. 2, pp. 7-9

[23] Zaha Hadid Ltd (2001) One North Masterplan, http://www.zahahadid.com/masterplans/one-north-masterplan/

[24] Jones (2006) Palimpsest of Progress: Erasing the Past and Rewriting the Future in Developing Societies, International Journal of Heritage Studies, Vol 12 (2) p. 124

[25] Lee (2007) National Day Rally Speech, http://www.pmo.gov.sg

[26] Chang and Huang (2005) Recreating Place, Replacing Memory: Creative destruction at the Singapore River, Asia Pacific Viewpoint, Vol 46 (3) pp. $267-280$

[27] Wong and Bunnell (2006) New Economy Discourse and Spaces in Singapore, Environment and Planning A Vol 38

[28] JTC Corporation (2001) Press Release, 4 December, www.jtc.gov.sg/Coporate/mdeia+room/4dec2001.asp

[29] Chong (2003) Launch of Fusionopolis, 20 Feb. http:// www.onenorth.com/ pages/pop-ups/news/content/speech12.htm 
[30] Horsey (1990) Tenements and Towers, RCAHMS, Edinburgh, p. 41

[31] Reoch (1976) Farewell to the Single End, The City of Glasgow District Council, Scotland, p 47

[32] Crown Street Regeneration Project (1992) Crown Street Regeneration Project: Past, Present and Future, Glasgow, p. 20 